"The EUrASEANs: journal on global socio-economic dynamics"

Volume 6 (25); November - December, Year 2020;

ISSN $2539-5645$ (Print)

Copyright (C) 2020, [The EUrASEANs]

on-line access: https://www.euraseans.com/6(25)

All issues of this journal are alternatively stored and archived by: the National Library of Thailand, Russian E-library and Index Copernicus

library of journals, Poland

\title{
CYCLICAL FLUCTUATIONS IN THE ECONOMIES OF V4 COUNTRIES
}

\author{
Eleonóra Matoušková \\ University of Economics in Bratislava, Bratislava, Slovak Republic
}

The Visegrad Four (V4) countries, which include Slovak Republic, Czech Republic, Poland and Hungary, are trying to catch up with the economic development and living standards of their more developed neighbours. The brake on this are economic recessions that regularly occur within market economies. The objective of this article is to assess the economic development in the V4 countries, in particular on the basis of development in the main macroeconomic indicator, which is GDP. All these countries went through two recessions in the 2008-2020 period. The first was the recession caused by the spillover of the global financial and economic crisis from the USA to Europe and thus to the V4 countries. During this crisis, the largest decrease was recorded in Hungary and in Slovak Republic. The second, and even stronger, economic crisis affecting the entire world economy and hence the $V 4$ countries too is the current crisis caused by the coronavirus pandemic and the measures taken to prevent its further spread. The highest decrease in GDP is projected in Slovak Republic (at -10.3\%) and the lowest in Poland (at -4.3\%).

Keywords: economic cycle, recession, Visegrad Four

\section{Introduction}

Economic development can be understood as the development of qualitative moments and concrete historical forms of the economic system. This is a broader category than economic growth, which deals with the monitoring of quantitative aspects (Varadzin, 2004). According to (Czesaný \& Johnson, 2012), economic growth is generally characterized by the phases of expansion (recovery) and contraction (slump) of economic activity. In contemporary economies, however, this is mostly about acceleration and reduction of the GDP growth rate. In other words, the economy continues to grow, but at a variable rate and oscillates around its potential product. A potential product expresses the highest and longterm sustainable product of a given economy, making optimal use of all the available production factors, without creating imbalances or further tensions in the economy.

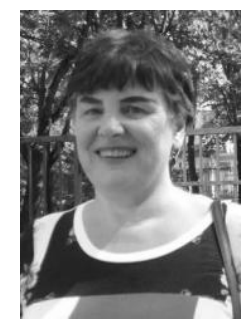

\section{Eleonóra Matoušková}

Ing., PhD., Assistant Professor, Department of Economic Theory, University of Economics in Bratislava, Slovak Republic

Research interests: business cycles, economic policy, heterodox economics.

E-mail: eleonora.matouskova@euba.sk 
The aim of the article is to assess the development of the economies of the Visegrad Four countries (Slovak Republic, Czech Republic, Poland and Hungary), mainly on the basis of development of their basic macroeconomic indicator which is GDP. The period under study is 2008 to 2020 .

\section{Literature review}

Traditionally, an economic cycle is understood as fluctuations in real GDP around the long-term upward trend in potential product development (Matoušková, 2015). In the real world, there will be constant changes due to shifts in consumer preferences and demand, available resources, technological knowledge, etc. We should therefore expect prices and output will fluctuate and consider the absence of fluctuations to be unusual (Rothbard, 1993). In the history of modern capitalism, the crisis is the norm, not the exception. However, this does not mean that all crises are the same (Roubini \& Mihm, 2011).

Maxton (2012) argues that economic growth should be seen as a happy consequence of activity, not as its intention. According to him, we also need to review the concepts of progress. Western economies have become obsessed with growth. Progress in society is measured by how economies grow, i.e., in monetary value. How economies grow depends largely on the consumption of societies. This is how we got to a rather strange point: without more consumption there is no more growth and without growth there is no progress.

In 1920, an institution for international business cycle research was founded - the National Bureau of Economic Research, or NBER, based in New York. The NBER became an internationally respected center for business cycle research. The scientists at NBER (and also others) have discovered that many economic and financial indicators could be grouped as "leading" the cycles, others as "coincident" with them, and still others as "lagging". A leading indicator, for instance, would tend to rise somewhat before general activity picked up - and fall somewhat before activity leveled off (Tvede, 2006).

\section{Economic cycle in the Visegrad Four countries during 2004-2012}

According to Cassidy (2009), the global financial crisis was a failure of monetary policy and economic analysis. Since the late 1990s, the Fed has stubbornly refused to acknowledge the dangers that speculative bubbles pose and has adopted a stance of nonintervention. The refusal to puncture stock market and credit bubbles was due to the fact that the Fed did not want to face attacks for causing an economic downturn. It believed that the economy was a self-repairing mechanism and that it would recover rapidly from any speculative crash.

At the time of the outbreak of the global financial and economic crisis, Slovakia's economy had been achieving positive economic growth for several years and the domestic banking sector was also reporting stability. However, economies of the main trading partners of Slovak companies have been put into recession. There was an external demand shock, which also affected the very open Slovak economy. In some way or another, almost two thirds of Slovak businesses were affected by the economic recession. Similarly, the consequences of the global financial and economic crisis have affected other Visegrad Four countries, to a greater or lesser extent. 


\section{CYCLICAL FLUCTUATIONS IN THE ECONOMIES}

Anti-crisis measures taken in the V4 countries (mainly in Slovakia, Hungary and Czech Republic) were little effective as can be seen in the GDP development chart. The fall in GDP was greatest in Hungary, where the value of the product fell by $-6.5 \%$ year-on-year in 2009 . In Slovakia, the economy has contracted by $-5 \%$ in the same year, and in Czech Republic by $4.5 \%$.

The situation was better in Poland as this country managed to maintain moderate GDP growth even in 2008 and 2009, the years when the global financial and economic crisis was the strongest in the other V4 countries. Reasons for more favourable development of Poland's economy can be found in labour productivity growth which has been positively influenced by the increasing rate of foreign investments. Also, in the course of 2008, the contribution of capital to the growth of private investment and hence to aggregate demand continued to increase. Another reason why Polish economy maintained positive GDP values was an explicit anti-global policy.

A reason for maintaining the positive rate of economic growth, even in the years of the strongest manifestations of the economic crisis in other V4 countries, has been the fact that Poland is a large economy and therefore not as dependent on foreign demand as the much smaller economies of Slovakia, Hungary and Czech Republic. The impact of the global financial and economic crisis on Poland's economy was therefore the weakest, as compared to other V4 countries. The employment rate in Poland remained almost unchanged in 2008 and then in the following years. Interestingly, it reached its peak of $65 \%$ in 2008 and was the only one among the V4 countries which did not start to decline even during the economic crisis. For this very reason, Poland's employment rate then exceeded the one in Hungary.

Economic development in the other three V4 countries was much more unfavourable. Slovakia, Hungary and Czech Republic experienced a rapid and significant decline in GDP and the economies fell into recession. The economic slump in all these countries reached its trough in 2009. More specifically, Slovakia's economy which in the pre-crisis years achieved high rates of economic growth (over 10\% in 2007) fell into negative figures due to its high dependence on exports of its products. This high decrease in exports in 2009 was reflected in the economic downturn of Slovak economy in a very short time. On average, for all V4 countries, the export rate decreased by $11.05 \%$, with the highest decrease being in Slovak Republic (16.3\%).

It can be concluded that the economic crisis had the worst impact on Slovak economy because it had high growth rates before the onset of the global financial and economic crisis - from around 5\% in 2004 to over $10 \%$ in 2007. Spillover of the economic crisis from the USA to Europe, namely to the economies of Slovakia's most important trading partners, has put the brakes on favourable economic development, not only in terms of GDP growth, but also in the field of employment. The employment rate in Slovakia had been increasing since 2004, reaching $68.5 \%$ in 2008. After the onset of the economic recession, it began to decrease, reaching $65 \%$ in 2010. The decline in employment in times of the economic recession can also be seen in Hungary and Czech Republic too.

Hungary's economy contracted the most among the studied economies in 2009, by $6.8 \%$. This decline was not only due to the effects of the global economic crisis on Hungarian economy, but also due to the previous stagnation or recession of Hungarian economy caused by the problematic situation with the state's fiscal policy. In the pre-crisis period, Czech economy grew at a rate of economic growth ranging from $4.5 \%$ to around $7 \%$, and similarly to Slovakia's economy, it was affected by the global financial and economic crisis due to a 
fall in exports, although the amplitude of the economic cycle was not so great as compared to Slovakia.
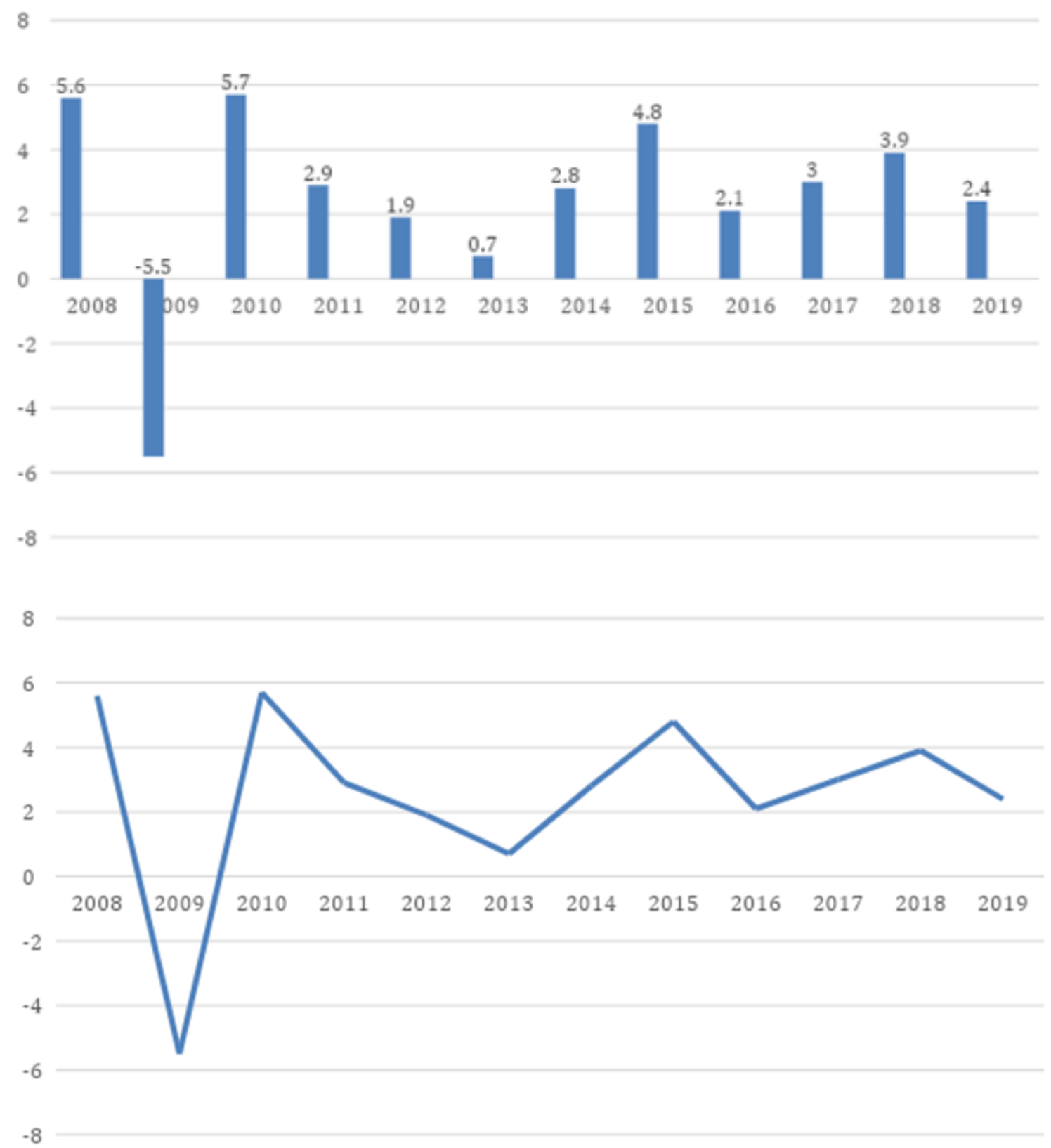

Figure 1 - Real GDP growth rate in Slovak Republic, percentage change to previous year (Source: made by the author according http://ec.europa.eu/eurostat) 


\section{CYCLICAL FLUCTUATIONS IN THE ECONOMIES}
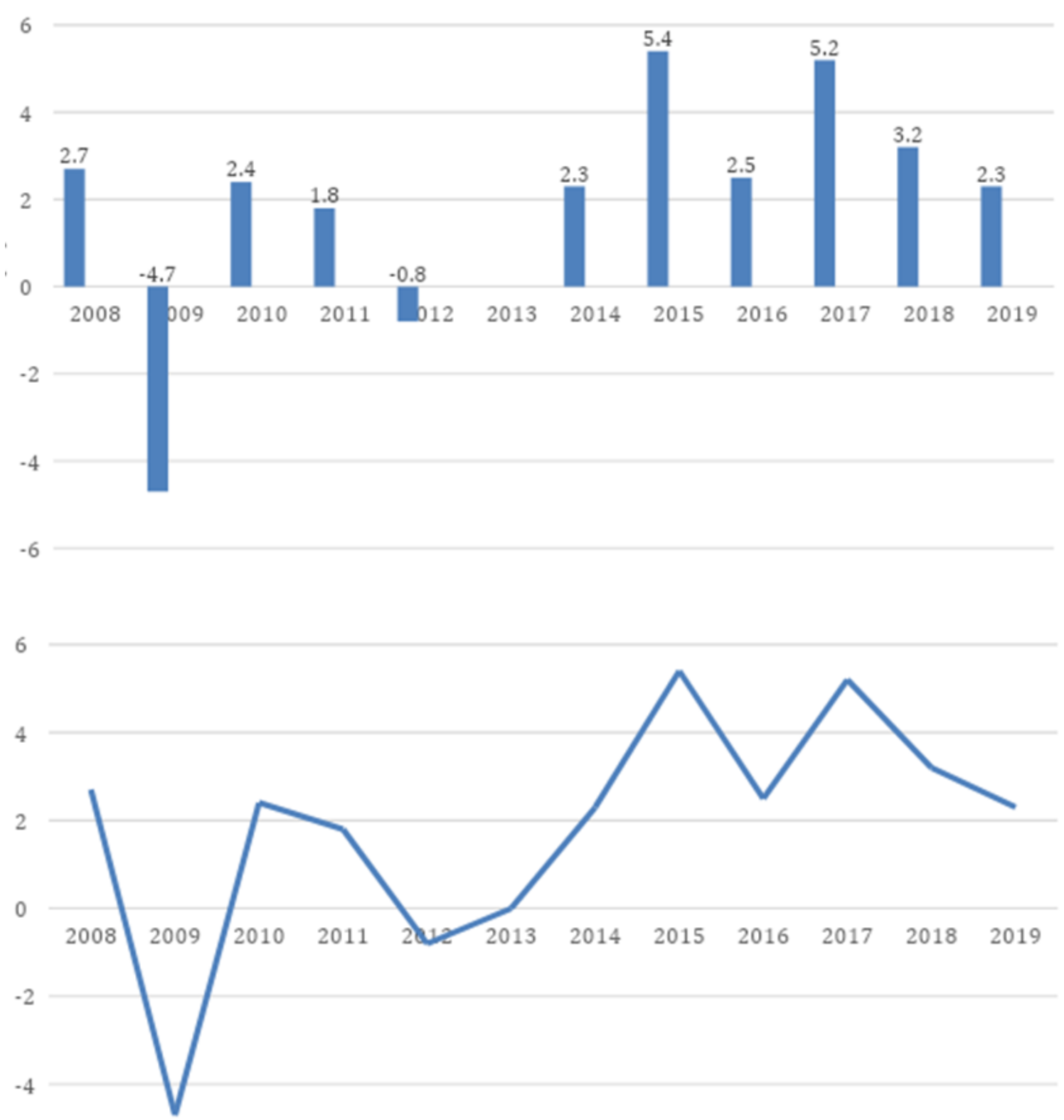

Figure 2 - Real GDP growth in Czech Republic, Percentage change to previous year

(Source: made by the author according http://ec.europa.eu/eurostat )

Czech Republic (as well as Hungary and Poland with their currencies) had the possibility to use the flexible exchange rate of Czech krona in the times of crisis. Slovakia, which adopted euro in 2009 and is one of the countries with a fixed exchange rate, could not benefit from the exchange rate flexibility and thus maintain the competitiveness of its products and the level of exports. The decrease in the employment rate in the countries with flexible exchange rates was much smaller than in Slovakia.

The European Central Bank began raising interest rates in the early 2011, even as the euro area economy was in recession, so there was no significant inflationary threat. Also, despite the ongoing economic recession in several countries, the OECD has called for 
monetary and fiscal tightening. At the end of 2009, both financial markets and the world economy stabilized and the need for rescue actions was no longer so urgent. Then came the Greek debt crisis, which created the need for fiscal responsibility (Krugman, 2012). This was negatively reflected in the return of recession in the economies of Czech Republic and Hungary in 2012 and in the slowdown of the recovery in Slovak Republic and Poland in 2012-2013.

\section{Economic cycle in the Visegrad Four countries during 2013-2020}

In the aftermath of the global financial crisis, economic growth resumed in Slovak Republic, but it was no longer at the pre-crisis levels. In the period 2003-2008, Slovak economy was the leader within the V4 countries in terms of economic growth rates. This was also repeated just after the recession, i.e., in the years 2010-2012. Since then, Slovak economy has not had such a position. The growth incentives that have driven the economy in the past have been exhausted, mainly the inflow of foreign direct investments (Frank \& Morvay, 2020).

After 2014, the unemployment rate in Slovak Republic fell significantly. It fell to 5.8\% in 2019. A new problem has emerged - the problem of labor shortages. The problem of labor shortages appeared in Slovakia later than in other V4 countries and was also more moderate. In Slovak Republic, labor reserves were available in the form of previously high unemployment. Labor productivity has lost its growth dynamics. But labor scarcity has pushed for an increase in labor costs.

The slowdown in the growth of Slovak economy occurred even before the coronacrisis. This was the expected cyclical slowdown, predicted back in 2018 already. Within the V4 countries, the slowdown was most obvious in Slovak Republic. The slowdown in the growth of Slovak economy was accompanied by a slowdown throughout the EU-28 though. Thus, the dynamics of foreign demand for goods from Slovak Republic decreased (Morvay, 2019).

A significant turning point came in 2020 due to the coronavirus pandemic. The current economic depression is primarily a supply shock (limitation of production due to labor force losses). Secondary is the demand shock (the lack of income of the labor forces leads to a drop in demand). The onset of the current economic depression was stronger than in the global financial crisis in 2009, and different types of economic activities are not affected equally (Morvay, 2019). Industrial production, exports and imports are significantly more affected than, for example, the construction sector. It can be expected that Slovak economy will be among those European economies that will be more affected by the economic depression, despite the relatively good epidemiological situation in the country. 
CYCLICAL FLUCTUATIONS IN THE ECONOMIES

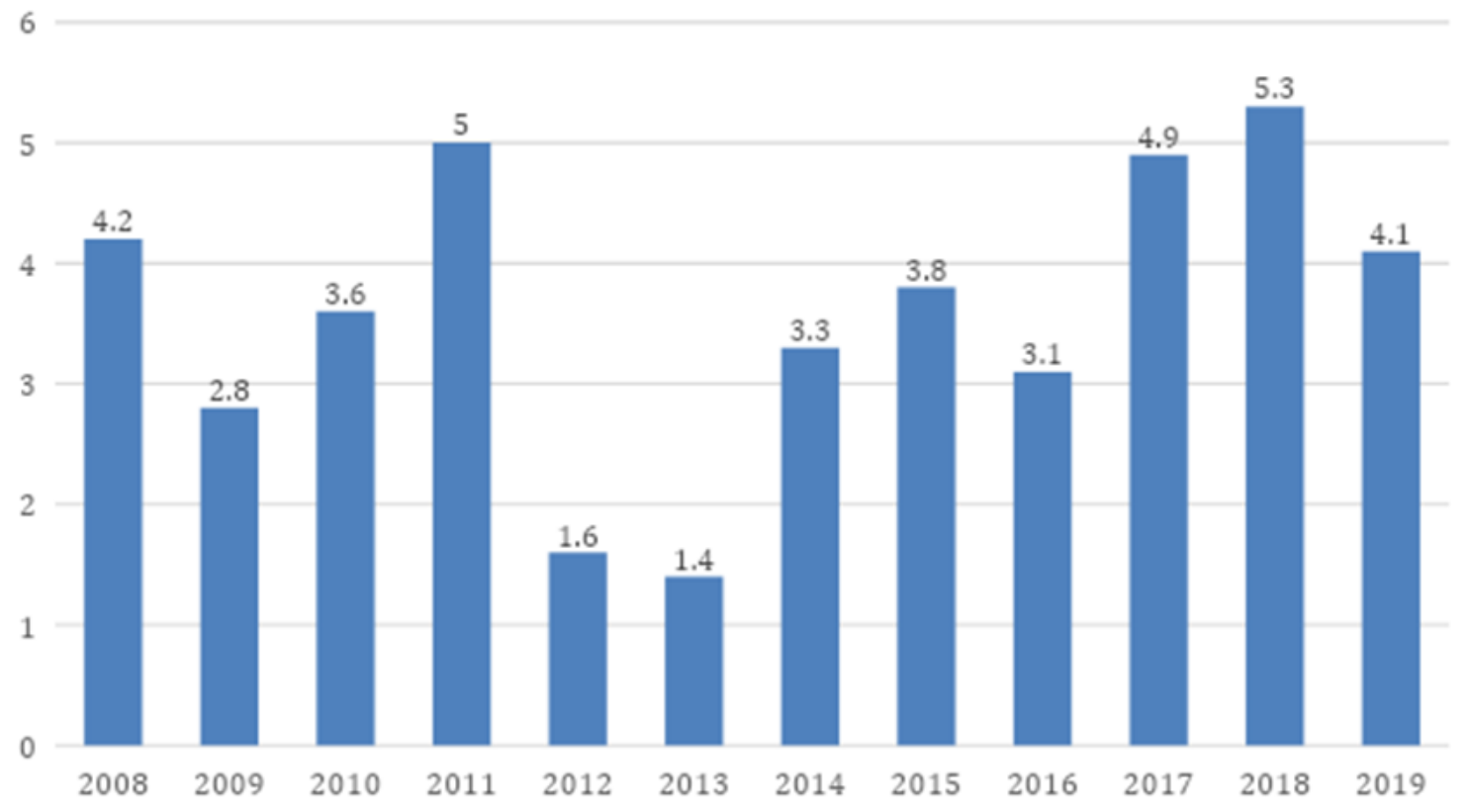

6

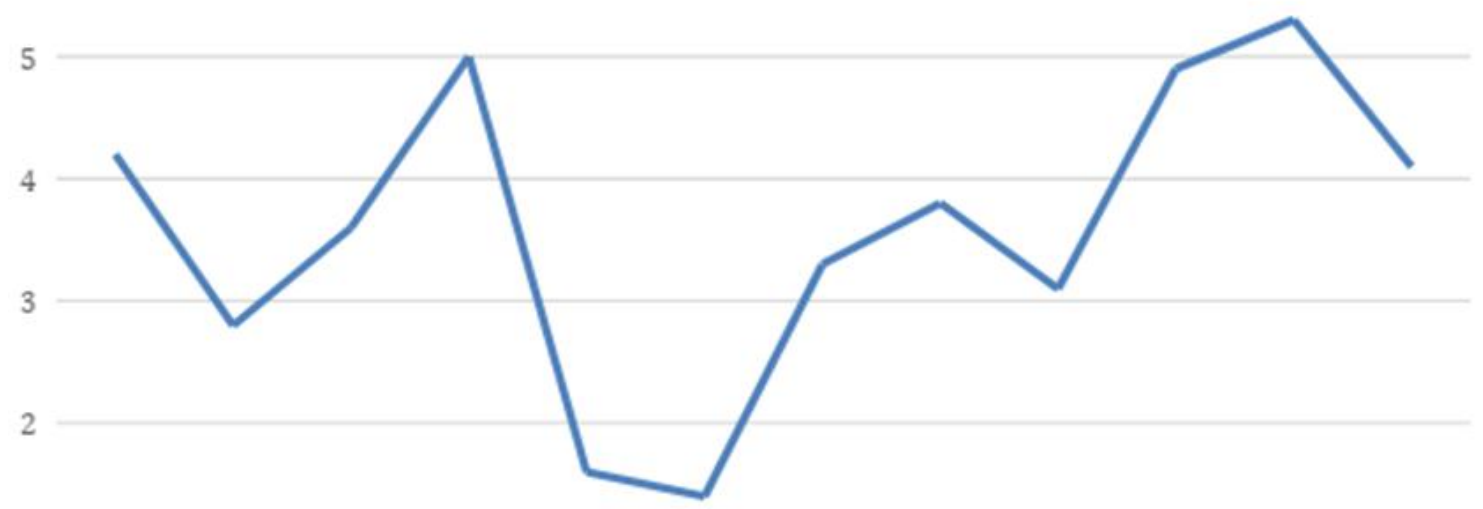

1

0

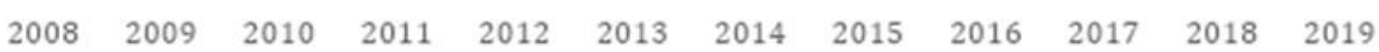

Figure 3 - Real GDP growth rate in Poland, percentage change to the previous year (Source: made by the author according http://ec.europa.eu/eurostat ) 

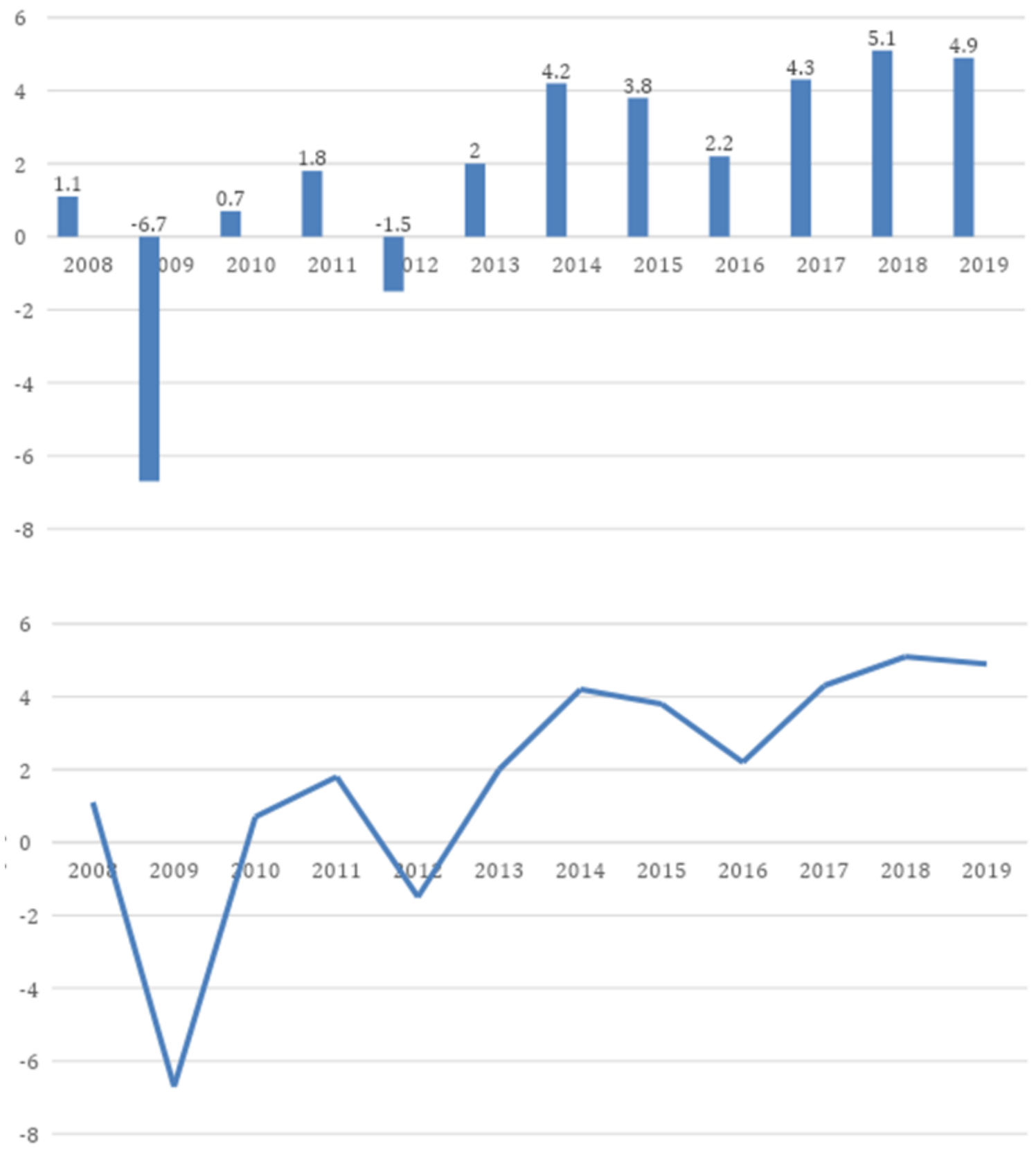

Figure 4 - Real GDP growth in Hungary, percentage change to the previous year (Source: made by the author according http://ec.europa.eu/eurostat)

Due to the pandemic situation in Slovak economy, the year-on-year indicator (in the 2nd quarter of 2020) of GDP decreased by $-12 \%$. Employment decreased by $-2.5 \%$ and the unemployment rate was $6.6 \%$. The GDP is now projected to fall by $-10.3 \%$ in 2020 overall.

In Czech Republic, the real GDP is projected to decline year-on-year at $-8.2 \%$. In the 2nd quarter of 2020, GDP fell by $-11 \%$, year-on-year. The unemployment rate stood at $2.7 \%$ in July 2020. It has increased, although Czech Republic has long been characterized by very low levels of the unemployment rate. Czech economy recorded its worst ever results in the 


\section{CYCLICAL FLUCTUATIONS IN THE ECONOMIES}

$2^{\text {nd }}$ quarter of 2020. The negative year-on-year development of GDP was caused mainly due to a significant decline in foreign demand, lower household consumption and lower investment activity. Significantly negative impact on macroeconomic development has had developments in industry, transport, accommodation and hospitality. Employment rate fell by $-2.1 \%$.

In Poland, GDP is expected to fall by $-4.3 \%$. It is the lowest indicator throughout the EU, actually. Even during the global financial crisis, Poland was the only EU country that managed to maintain economic growth.

In Hungary, the coronacrisis has hit both services and industry. The key reason (as in many other countries, actually) was directly related to the tough measures taken to prevent the spread of the coronavirus. In year-on-year comparison, Hungarian GDP decreased by 13.6\% in the second quarter of 2020. The European Commission expects Hungary's GDP to fall by $6-7 \%$ in 2020 .

\section{Conclusion}

During the period 2008-2020, the economies of all Visegrad Four countries went through a similar economic cycle. All these economies were affected by two recessions, each of which had a different cause. In 2008-2009, the countries went into recession as a result of the spillover of the global financial and economic crisis from the USA to the EU and from the EU to individual V4 countries. Slovakia, in particular, experienced a major slump in the economy, as it was at a very high growth rate (approaching 10\%) before the recession broke. The economies have recovered in a relatively short period of time, but Slovakia was far from its pre-crisis level. Even in 2012, the economies of Czech Republic and Hungary were still in a mild recession, with the tightening of fiscal measures in the context of the deepening of the EU debt crisis. Of the V4 countries, only Poland did not get into negative numbers during this crisis and economic growth was "only" reduced from $4.2 \%$ to $2.8 \%$ in 2009 and from $5 \%$ to $1.4 \%$ in 2013.

The second crisis during the reporting period occurred in 2020, triggered by the coronavirus pandemic and the measures taken to prevent its spread. This is a crisis caused by external, non-economic reasons. It first became apparent on the supply side due to labour constraints in several sectors of the economy. Consequently, it also became apparent on the demand side, as redundancies and work restrictions reduced the incomes of many households. It is forecasted to become the biggest crisis since the Great Depression back in the 1930s. The problem remains that the pandemic continues to persist and it is not possible to predict with certainty when it will finally end. This remains a major risk for further economic development, not only in the economies of the V4 countries, but throughout the global economy.

\section{Acknowledgement}

The article was prepared in the framework of the research project VEGA 1/0239/19 "Implications of behavioral economics to make the functioning of current economies more efficient". 


\section{References:}

Cassidy, J. (2009). How Markets Fail: The Logic of Economic Calamities. Praha: Academia.

Czesaný, S. \& Johnson, Z. (2012). Ekonomický cyklus, hospodářská politika a bohatství zemè. Praha: Oeconomica.

Frank, K. \& Morvay, K. (2020). Hospodársky vývoj Slovenska v roku 2019. Bratislava: EU SAV.

Krugman, P. (2012). End This Depression Now! Praha: Vyšehrad.

Matoušková, E. (2005). Hospodársky cyklus. Bratislava: Ekonóm.

Maxton, G. (2012). The End of Progress. How Modern Economics Has Failed Us. Chichester: John Wiley \& Sons.

Morvay, K. (2019). Hospodársky vývoj Slovenska v roku 2018 a výhl’ad do roku 2020. Bratislava: EU SAV.

Rothbard, M. N. (1993). Man, Economy, and State - A Treatise on Economic Principles. Ludwig von Mises Institute.

Roubini, N. \& Mihm, S. (2011). Crisis Economics, and Crash Course in the Future of Finance. Praha: Grada Publishing.

Tvede, L. (2006). Business Cycles. History, Theory and investment reality. Chichester: John Wiley \& Sons.

Varadzin, F. (2004). Ekonomický rozvoj a růst. Praha: Professional Publishing.

Paper submitted

Paper accepted for publishing

Paper published online
28 June 2020

14 September 2020

30 November 2020 